\title{
PERSONOLOGY OF DIFFICULT LIFE SITUATIONS: AT THE INTERSECTION OF THREE CULTURES
}

\author{
V.A. PETROVSKY ${ }^{\mathrm{a}}$, I.M. SHMELEV ${ }^{\mathrm{a}}$
}

${ }^{a}$ National Research University Higher School of Economics, 20 Myasnitskaya Str., Moscowe, 101000, Russian Federation

\begin{abstract}
The paper focuses on the analysis of phenomena involving the individual's handling of difficult life situations (DLS). Handling DLS is interpreted in the context of "three cultures": in the interrelation of the culture of scientific knowledge, the "ideofield of culture" and the culture of individual experience. Existing theories of individual response to difficult situations are analyzed; it is shown that the methodological core of most concepts is the "postulate of conformity" ("adaptability") when interpreting human behavior. Along with the well-known "defensive" and "coping" behaviors that are adaptive in nature, non-adaptive forms are distinguished ("selfdestruction" and "mastering"), and a two-dimensional typology of addressing DLS is proposed based on the distinction between "activity/passivity" and "adaptability/non-adaptability". Selfdestruction is characterized as passive non-adaptive behavior (disadaptation); "defense" means passive adaptive behavior (actually, adaptation to the situation); coping is active adaptive behavior (overcoming the situation); and mastering is active non-adaptive behavior (overcoming difficulties). Three ways of mastering are described: post-factum simulation of situations; a testing of the individual's capabilities in a previously unknown situation ("emotional flutter"); and "emergency simulation for future use". The ways to reflect upon the person's own behavior in a DLS are also considered to transform the two-dimensional model into a three-dimensional one to reveal the attitude of an individual to difficult life situations. It is demonstrated that in the subjective plane (the semantic aspect of self-reflection) a picture of the methods used to handle a DLS that is "drawn" by an individual may significantly differ from the objective picture of what is happening (that is established according to the criteria of scientific knowledge). This paper presents a model of the personological synthesis of the three cultures for interpreting and correlating the forms of the person's handling DLS. In this context, some techniques are described that enable the co-organization of individual experience, elements of the "ideofield of culture" and scientific knowledge to contribute to altering the individual's attitude to difficult life situations and increasing the meaningfulness of their personal behavior.
\end{abstract}

Keywords: personology, culture, difficult life situation, addressing difficulties, self-destruction, defense, coping, mastering, meaning, attitude, meta-position.

\section{Introduction}

We believe that the Personology of Difficult Life Situations (DLS) is one of the new directions in the psychology of personality. We should recall that "general personology" (the science of personality) is a methodology for the synthesis of fundamental, 
practical and cultural psychology (Petrovsky, 2003; Petrovsky \& Starovoytenko, 2012). The focus of personology is the non-trivial and informative aspects and existential significance of scientific propositions and facts (as well as of cultural texts) as potential "psychological tools" of personality change and development in the context of consultations.

We should emphasize the originality of the study. The apparent plethora of studies on the personal manifestations of people in DLS, and the undoubted importance of solving this problem for practice, leave unasked the question of how fundamental psychology (theoretical-empirical $-\Psi \Lambda-1$ ) and practical psychology (psychological counseling, psychotherapy $-\Psi \Lambda-2$ ) correlate in this field; the other question is of the role the cultural psychology of personality $(\Psi \Lambda-3)$ could play in the correlation of "two psychologies" (Petrovsky \& Starovoytenko, 2012).

In the psychological literature there is a situation that could be called a "balance of deficiencies": psychotherapists and consultants from various schools lack the accuracy of test diagnostics of the individual in a situation of DLS, while "academic psychologists" lack the subtleties of phenomenological analysis.

"One result of this wider fissure is that psychodynamic formulations of personality and psychopathology, which emerged more from clinical experience and naturalistic observation than from the laboratories of academic psychologists, have too often been portrayed to university students as archaic, irrelevant, and empirically discredited. Although decades of research on analytic concepts are typically ignored when current critics idealize specific evidence-based treatments-in their 1985 and 1996 books, Fisher and Greenberg reviewed over 2,500 such studies-the paucity of randomized controlled trials of open-ended psychodynamic therapy has cost us dearly. In addition, the arrogance of many analysts in the heyday of psychoanalysis, especially their belief that what they experienced with each patient was too idiosyncratic to be researchable, contributed to negative stereotypes held by nonclinical colleagues" (McWilliams, 2015).

When we look from the side (through the eyes of a general personologist) there is a relationship between $\Psi \Lambda-1$ and $\Psi \Lambda$-2 of mutual compensation, although both of them, it would seem, do not need any kind of replenishment from "subcontractors". But, within the approach of general personology the question is not to recognize the balance of deficits and the possibility of mutual compensation of $\Psi \Lambda-1$ and $\Psi \Lambda$-2. Rather, it is necessary to establish cooperation providing the effect of synergy and the synthesis of theoretical-empirical and practice-oriented approaches. In this context $\Psi \Lambda-3$ reveals its function playing the role of a mediator.

What, specifically, could be a condition for the synthesis?

First of all, it is necessary to formulate ideas about DLS that would be equally acceptable for the development of fundamental and practical psychology, and to offer in this context a common name that can be used for all, without exception, personal manifestations in DLS.

Secondly, to develop such a typology of personality's activity in DLS that, being the result of theoretical and empirical developments, could act as a guideline for the work of a practitioner psychologist on reorganizing individual ways of people's handling such situations. 
Thirdly, to give a hypothetical description of the differences between the life meaning of the personality's manifestations of a person in DLS, and the personality meaning of acts delivered in such conditions.

Fourthly, to consider possible cultural prototypes of personal manifestations in DLS.

Fifth, to suggest possible ways to promote the individual in building conscious, rational forms of behavior in a DLS.

In general, we mean the task of the personological synthesis of the culture of scientific knowledge, the ideofield of culture, and the culture of a personality's individual experience in difficult situations of life.

\section{"Three Cultures"}

Speaking about the culture of scientific knowledge, we mean, first of all, what $\mathrm{T}$. Kuhn called the "paradigm". The scientific paradigm is a set of knowledge, methods, and models of problem solving; it also includes values shared by the scientific community. As applied to the problem of DLS, the question of the paradigm that is "functional" at present (does exist, or are psychologists at the level of pre-paradigm knowledge; are there values shared today by the whole scientific being?) cannot be considered solved. Only recently, in the seventies of the twentieth century, the dominant principle in the understanding of human behavior and consciousness was the "conformity postulate", a hidden methodological setting to interpret the manifestations of all living things, including humans, from the position of adaptability and the urge to follow an internal goal, a deviation from which was considered a pathology or a sign of immaturity (Petrovsky, 1975). From this point of view, a difficult life situation could be considered (and was considered) as a cause for manifesting the ability to "adapt" (more details on this further in the paper). Nowadays a different view is gradually being asserted: the motives are identified for development (Allport, 2002), heterostasis (Rogers, 1951; Maslow, 1981), preadaptivity (Simonov, 1975; Asmolov, Cherenorizov, \& Shekhter, 2017), and "supra-situational activity" (Petrovsky, 1975, 1996, 2010). A general view of a person as an adaptively non-adaptive being is born, the paradigm of subjectness ${ }^{1}$.

The ideofield of culture. We use this successful term that was introduced not without grace by V. S. Mukhina as a family name for many phenomena that characterize the public consciousness ("collective representations", "the all-inclusive and unconditional consciousness", "semiosphere", etc.). The similarities are quite obvious between the "ideofield of culture" and "social (collective) representations" in the theories of Durkheim (Durkheim, 1995), Moscovici (Moscovici, 1995), etc.; however, V. S. Mukhina (Mukhina, 2009) places a special and important focus for us on language elements and archetypical images in the behavior patterns of cultural heroes (the list of archetypes under consideration is much broader than the

\footnotetext{
${ }^{1}$ At the time when one of the authors was writing and defending the thesis "The Phenomenon of Subjectness in Personality Psychology" (Petrovsky, 1992), the term "subjectness" was actually absent in the scientific literature. Today it is one of the high-frequency terms in Russian psychology.
} 
Jungian one $\mathrm{e}^{2}$ ). In addition, the word "field" embodies the idea of attraction and the hidden synthesis of its constituent elements, in contrast to the "totality" depicting the cultural environment of a person as something fragmentary. In the context of the analysis of DLS we will discuss below the specific components of the ideofield of culture.

The culture of individual experience. When distinguishing this "hypostasis" of culture, we mean implicit theories of personality, "meanings", "idiolects" (individualized languages), and attitudes of personality. In this study we emphasize the discrepancy between the means by which a person interprets his/her difficulties, the way he/she understands them, and how these ideas "exist in the science and in the ideofield of culture.

\section{The Difficult Life Situation; “Addressing” Difficulties - a Scientific View}

Normally a difficult life situation is understood as any situation with high levels of uncertainty and significance for a person. At the subjective level it is perceived as interfering with the achievement of a goal and can cause feelings of distress. Usually these are stressful situations, with an increasing sense of anxiety; conflict situations that contribute to the activation of psychological defenses; frustrating situations in which the ambivalence of feelings manifests itself, as well as cognitive and behavioral disorientation; situations that cause a feeling of neuro-psychological stress; traumatic situations with a high risk of threat to life followed by posttraumatic stress disorder (PTSD); extreme situations contributing to the mobilization of human strength and capabilities; life threatening emergency situations (for example, floods or earthquakes) (Libina, 2008).

The last three of them (traumatic, extreme, and emergency) are not considered to belong to the category of DLS that we study: the way they occur, the amount of time that they last and the nature of their influence are virtually independent of the person. We are interested in situations, the nature and effects of which are mediated by the activity of the person themselves. This distinction should be clarified since most of the "difficult life situations" are interpreted in the ordinary perception of people as an objective reality, and this perception contradicts the essence of what is happening (we will further indicate studies that show that experiencing difficulty is mediated by cognitive assessment of situations ${ }^{3}$ ).

So, in our understanding, a "difficult life situation" is a situation experienced by the subject as interfering with the achievement of his/her goals (realization of their interests) and at the same time containing a hidden resource that allows them to be realized. DLS can exist "here and now" (at this moment of a person's life), but also "there and then" (in the past or in the future): as something "lived through" or something probable, expected. The reliance on the hidden resource may be active or passive in nature.

\footnotetext{
${ }^{2}$ On the concept of the "The Great Ideofield of Culture" V. S. Mukhina (see Petrovsky, 2015).

${ }^{3}$ From a broader perspective, handling DLS can be considered as the main content of psychological counseling and psychotherapeutic work, - in fact, as the subject of these disciplines.
} 
In this definition, unlike the definitions proposed by some authors, for example A. V. Filippov and S. V. Kovalev (Filippov \& Kovalev, 1986), N. G. Osukhova et al., emphasizes the presence of a subjective element constituting DLS. The same idea is presented in the work of E. V. Bityutskaya and V. A. Petrovsky (Bityutskaya, Petrovsky, 2016) indicating, in particular, the involvement of the fund of biological experience when forming the initial "reading" of circumstances as difficult; thus, in our opinion, the fact is noted of the actualization of unconscious reactions to stimuli that exist "on the other side" of personal experience, and this would be difficult to classify as a subjective appraisal. It is logical to assume that these are motivational and affective reactions. Such an understanding follows from the classical works of R. Lazarus and S. Folkman, where "primary" and "secondary" appraisals are described (Folkman \& Lazarus, 1998).

It is implied that in a difficult life situation the internal resources for moving toward a goal that are additional to individual standards are actualized and realized.

Speaking about personal manifestations of an individual in a DLS, we use a new phrase: addressing difficult life situations (difficulties), referring to two categories of phenomena: reactions to current DLSs and actions related to potential DLSs.

A characteristic feature of all (without exception) conceptual constructs of psychologists working with DLS, is the emphasis on the adaptive nature of people's response in situations that can be classified as difficult (stress, frustration, crisis, collapse, etc.). Such a view wholly corresponds to the canons of empirical psychology of personality that interpret the behavior and consciousness of people as a manifestation of an adaptive (in a broader sense, teleological) orientation. This canon appears in psychology under the name of the "conformity postulate" (Petrovsky, 1975). It is implied that there is a certain common Goal (hedonistic, pragmatic, homeostatic, etc.) that underlies all private goals and motivational tendencies of an individual (including products of fantasy, dreams, etc.). The multifaceted theoretical and empirical criticism of the "postulate" has been provided by V. A. Petrovsky and his colleagues during all these years until recently, but the power of the postulate is such that its traces of it can be found in most modern works: researchers believe (although they do not declare this) that in situations of real or potential difficulties there is the only one way of behavior, - adaptive 4 .

The teleological orientation (the "conformity postulate") is traced in such approaches to the problem of addressing DLS in all, without exception, trends in the empirical and clinical psychology of personality. Among the most famous approaches there are:

1. The psychoanalytic approach. Representatives of this approach implemented in the context of the problem under discussion are G. Vaillant (Vaillant, 1977), N. Haan

\footnotetext{
${ }^{4}$ In the most recent years exceptions to this rule have been appearing. For example, the large-scale and deeply grounded work of E. V. Bityutskaya (that we find rather close to our ideas in the approach and, we would say, akin in meaning), examines the determinants of the activity of the individual towards difficult life situations. This approach, as the author of the study notes, is based, in particular, on the idea of supra-situational activity that implies the actions of a person "above the threshold of situational necessity" that goes beyond adaptation to the situation (Bityutskaya, 2018, p. 43).
} 
(Haan, 1965; 1977; 1969) and T. C. Kroeberg (Kroeberg, 1963). It originates from the classical psychoanalysis of S. Freud and A. Freud. Resolving difficult life situations is seen as a way to eliminate tension. Protection mechanisms are treated as functioning without the involvement of consciousness and used for self-defense.

2. The situational approach that draws attention to the analysis of problemfocused/emotionally-focused coping strategies. R. Lazarus and S. Folkman (Lazarus $\&$ Folkman, 1984; Folkman \& Lazarus, 1998) are the founders of this approach. They linked specific strategies of coping behavior to a specific situation. From their point of view, the situation itself (and not the personal qualities of an individual) sets the choice of style in the individual behavior. R. Lazarus and S. Folkman defined "coping behavior" as the sum of the cognitive and behavioral efforts that a person applies to reduce the effects of stress (Nartova-Bochaver, 1997).

3. The procedural approach, in which researchers propose classifications, where coping strategies are separated based on identifying three types of processes: emotional, behavioral, and cognitive, E. K. Koplik (Koplik, Lamping, \& Reznikoff, 1992). All processes are intended as adaptive.

4. The existential approach. Existential psychology is of particular importance in the study of coping (V. Frankl, I. Yalom, R. May, A. Längle, and others). DLSs encourage people to overcome the emotional and spiritual vacuum and their experiences of the meaninglessness of being.

5. The integrative approach. It is characterized by the analysis of effective or ineffective coping strategies according to the criterion of adaptability in its pragmatic interpretation (the measurement of efficiency and inefficiency) (Frydenberg, Lewis, 2000).

6. The cultural and phenomenological approach. So far absent. The development of this approach in the format of general personology could complete the picture (this paper presents an attempt to outline the contours of the cultural and phenomenological approach).

By rejecting the totality of the "conformity postulate" as the only possible way of interpreting the phenomenon we are interested in, we are expanding the range of forms of the personality's possible manifestations in difficult life situations, assuming their cultural mediation, and this forms the methodological guideline of the study being undertaken.

Traditionally, of all the ways of dealing with a DLS only reactions to difficulties encountered are considered: defensive behavior and coping (that have an exclusively adaptive nature). Copings (coping behavior) are contrasted to defenses that possess an unconscious nature; however, non-adaptive responses to such situations are not considered.

Going beyond the limits of the action of the "conformity postulate", we single out non-adaptive forms of handling DLS and among them maladaptive reactions, as well as actively non-adaptive manifestations of the subject.

In a special empirical study (Shmelev, 2017) we tried to distinguish between such forms of addressing DLS as defense, coping and mastering behavior. An exploratory and confirmatory factor analysis was done of the respondents" answers to the questions of Ways of Coping Questionnaire (WCQ) developed by R. Lazarus 
and S. Folkman 5 , E. Heim's "Method for the Determination of Individual Coping Strategies" (MDICS) and the method of expert assessments (the total number of respondents was 335; 96 men and 239 women 18 to 32 years old); it was possible to distinguish three forms of dealing with difficult life situations, "defense", "coping", and "mastering" (the fourth form, "self-destruction", is outlined hypothetically).

Defense is represented by the following answers to the WCQ questionnaire about possible ways of addressing difficult life situations: "venting one's annoyance at those who got me into this trouble"; "was looking for someone's sympathy and understanding"; "spoke to someone about my feelings"; "generally avoided contact with people"; "projected it onto other people"; "imagined and fantasized how all this might have played out"; "asked for advice from a relative or my respected friend".

Coping was represented in the following answers: "I resigned myself to fate: it happens that I have no luck"; "I spoke to someone who could give me some practical help in this situation".

Mastering was presented in the following answers: "I was attempting to see the advantages of the situation"; "I was changing or growing as a person in a positive direction"; "rediscovered something important for myself"; "I was aware of what should be done and redoubled my efforts to fix everything"; "I changed something in myself"; "I found a couple of alternative ways to solve the problem".

So, the proposed typological model for addressing DLS includes the following forms determined by the oppositions of activity/passivity and adaptability/nonadaptability (Shmelev, 2017) (see Table 1):

1) defense, passive adaptive behavior;

2) coping, active adaptive behavior;

3) mastering, active non-adaptive behavior;

4) self-destruction, passive non-adaptive behavior.

Table 1

A Model of the Description of Addressing Difficult Life Situations

\begin{tabular}{|c|c|c|}
\hline & ADAPTABILITY & NON-ADAPTABILITY \\
\hline ACTIVITY & COPING & MASTERING \\
\hline PASSIVITY & DEFENSE & SELF-DESTRUCTION \\
\hline
\end{tabular}

We shall consider in more detail the content of the table.

1. Defense (passive adaptive behavior). Here such methods of dealing with a DLS are found as primitive avoidance, denial and depreciation, all-powerful control, ego splitting, projection, introjection, projective identification, somatization, etc. (psychoanalysis); fusion, retroflection, etc. (gestalt therapy); cognitive distortion (cognitive behavioral psychotherapy); aggression, activism, avoidance, reflex

\footnotetext{
${ }^{5}$ The description is presented in the works of R. Lazarus and S. Folkman (Folkman \& Lazarus, 1998; Lazarus, 1993; 2006). The questionnaire was adapted by a team of researchers supervised by $\mathrm{L}$. I. Vasserman, Bekhterev Psychoneurological Institute).
} 
of imaginary death, etc. (personal existential analysis); contamination, ignoring incentives, problems and opportunities for change, and the ability to cope (transactional analysis).

2. Coping (active adaptive behavior). Here are such ways of dealing with a DLS as: distancing, escape and avoidance, seeking social support, self-control, assuming responsibility and a positive reassessment of the situation (the situational approach to coping behavior (R. Lazarus, S. Folkman)); cognitive coping strategies: informational search, informational closeness (procedural approach), planning, acceptance, search for emotional social support, deterrence, etc. (the theory of C. Harver and colleagues); ignoring, humility, religiosity, attributing a meaning, etc. (the theory of E. Heim).

3. Mastering (active non-adaptive behavior). In this case there are three ways of treating a DLS:

1) a post-factum simulation of situations similar to those previously lived ("acquiring" the experience of coping); at the same time, the person learns an important lesson that gives meaning to a new test;

2) testing one's capabilities in a previously unknown situation (gaining experience of coping), "emotional flutter" (Shmelev, 2015) that means a state of heightened tension and instability associated with the uncertainty of a positive or negative outcome (in aviation the word "flutter" means "bumpiness" when breaking the sound barrier).

3) emergency simulation for future use, the search for a DLS in order to model own potential to cope with it and the consequences of coping with it; the idea of emergency simulation is formulated by V. A. Petrovsky, along with other forms of supra-situational modeling: "boundaries modeling", "innovative modeling", and "frustration modeling" (Petrovsky, 2010). “... A person as if is trying to experience (or explore) what the negative prefix/suffix could mean in the words "unknown", "incredible", "intolerable", "infinite", "unaccountably", "useless” (Petrovsky, 2005, p. 141).

4. Self-destruction (passive non-adaptive behavior). This is maladaptive behavior, various forms of capitulation in the face of difficulties. Addiction forms an example of self-destruction. Such people may or may not be aware of their condition. After treatment and psychotherapy, they can change their attitude towards physical and psychological health (Lisetsky \& Lityagina, 2014).

In particular, existential escapism can be associated with such behavior (Litinskaya, 2012), that is, compulsive self-awareness as an escape from reality, an excessive "self-probing" (E. Erickson localized the origin of this form of response to DLS in the third phase of personal development, i. e. an "initiative vs. guilt" (Erickson, 2002). Escapism is characterized by excessive reflection, the urge to replace activities in the real world with reflections on them and an obsession with

\footnotetext{
${ }^{6}$ The movement of culture, as it always means going beyond the boundaries of the established forms, is determined by the challenges from these boundaries, by the temptation on their part, and by the desire to unravel: "what is 'beyond'...". "All poetry is a venture into the unknown" (V. V. Mayakovsky).
} 
self-analysis without the ability to make contact with others. The person's focus on their personality, on their personal ideas that isolate him/her from significant others is an important indicator of this behavior. The central element connecting all the "strategies of dying" is the tendency to withdraw into virtual worlds, imaginary realities, as well as the dependence on a fantasy world, lack of adequate connection with reality, and unwillingness to personalize in others. Contrary to the desire to be reflected in other people (to find one's own ideal representation, otherness in others) that is normal in a fully functioning person (Petrovsky, 2010), the individual withdraws deeply into themselves and focuses on their own emotions and feelings. Such an individual cannot express themselves as a person, that is, as E. B. Starovoytenko believes, they cannot enter into dialogical relations, manifest themselves in "the forms of deed, accomplishment, a large-scale influence ... on other people" (Starovoytenko, 2004, p. 66).

It is important to emphasize that this thesis requires additional justification since self-destruction (as a passive non-adaptive form of response to the challenge of the world) is not a defensive behavior; it is phenomenologically and virtually distanced from "defenses" (but is not a "defense"). As noted above, the tendency to reduce all forms of stress response to defenses and copings (adaptive forms of behavior) is a tribute to the "conformity postulate" (that explains everything that happens to a person or in a person by the action of hidden motives). Obsession with risk-taking, delinquent behavior, and depression that induces suicide and often ends with it, can be as a counterexample (in this case, only by distorting facts can depression be interpreted as an "adaptation", but such interpretations are present in the literature). Similarly, for example, a stupor ("numbness") in some cases can be a source of disastrous consequences for a person's existence. Therefore, speaking of maladaptive forms of response from the "undergoing I" ("passive", "suffering", "dependent"), we deliberately exclude them from the category of defenses, coping and mastering, and give them the status of a degenerate case of responding to DLS.

Developing the personological interpretation of the forms that people use to address difficult life situations, we approach an issue that, like in other cases, is both of theoretical and practical interest. This is an issue concerning the meaning of the selected forms in the system of relations of the subject.

This opens the third dimension in the specification of the forms that people use to address difficult life situations. Here each of the four forms is evaluated in terms of its meaningfulness in the context of the person's life and relations. Metaphorically speaking, a certain "point" appears in space, above the plane of the selected forms of addressing DLS, which allows us to "examine" and evaluate their meaningfulness from the outside, from the position of a bystander or participant observer (Figure 1).

D. A. Leontiev in his monograph "The Psychology of Personal Meaning" (Leontiev, 2003), introduces the concept of "life meaning", emphasizing its metaphysical nature. Simply put, it is about what people in our culture consider reasonable or not from the point of view of "common sense". In fact, such an approach does not simplify the problem: observing the behavior of living beings of any degree 


\section{Metapositions of External and Internal Observers}

Figure 1
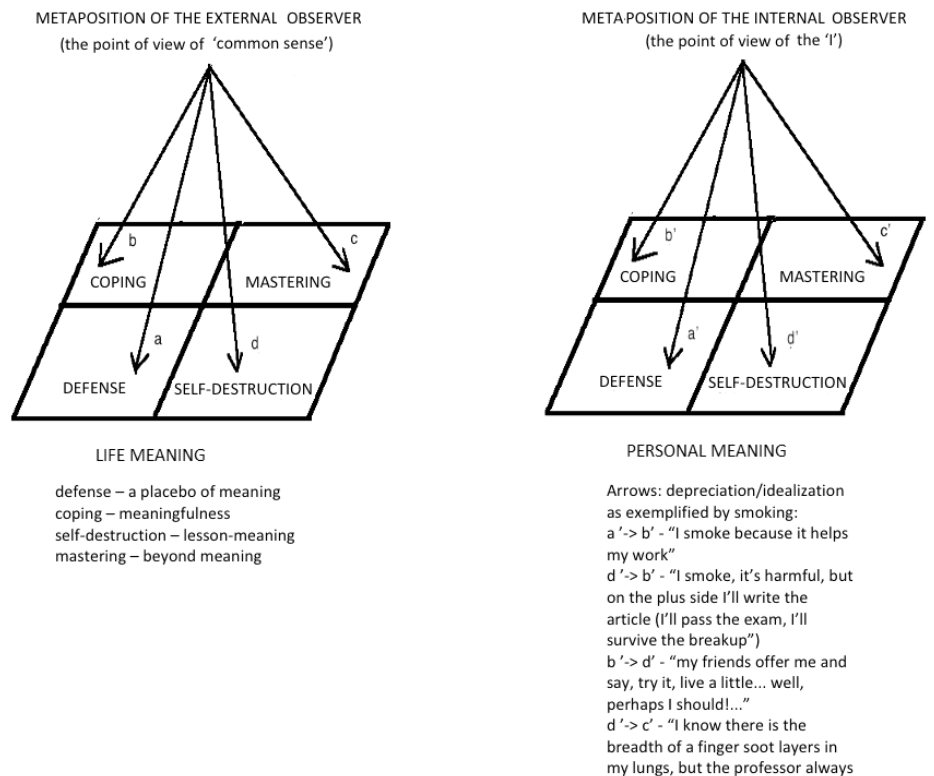

of complexity does not directly reveal to us the meaning of their actions ${ }^{7}$. The solution to the question is determined by how exactly we interpret the meaning (for example, survival as reproduction ${ }^{8}$, gene transfer in a generation, pre-adaptation, protection of the interests of the genus, etc.). At the individual's level meaningful being can be considered the realization of primary motives (they are called "meaningful" (Leontiev, 1975), including the "motives of development", the realization of hidden

${ }^{7}$ "The simplest example of a biological trick can be found in domestic hens. From a sentimental point of view, a hen's story is this: having laid eggs, it hatches them with inconspicuous devotion. From time to time, with the foresight of an experienced midwife, it turns them over so that the beneficial heat of its body can penetrate into all parts of the shell-covered wombs, where its brood incubate. And in the end, as a result of its constant cares, healthy chickens hatch from the eggs. Thus, it provides the human race with an indisputable example of rational and decisive motherhood.

In reality, the following happens. After it laid a heap of eggs, certain glands cause overheating in the front of its body. Tormented by this unpleasant sensation, it looks around in search of how to cool its burning chest. And it sits on the eggs, because they are cool. But after a while, the eggs heat up, and it turns them over to take advantage of their more pleasant cold side. After a sufficient number of these procedures, the eggs burst, and the hen finds itself, to its considerable surprise, in front of a brood of chickens" (Berne, 2017, pp. 204-205).

${ }^{8}$ The criterion of life, according to V. M. Rivin (Mikhailov), is that a living creature as a bodily totality exists longer than any of its parts. The same idea can be expressed metaphorically: the living being is the whole that perseveres its spatial organization and wins time (surpasses the life of its own parts) (Petrovsky, 2013, p. 14). 
motives. In the latter case it is said: "a person should strive to become what he/she can become" (but no one knows in advance how this trial may end for the subject and there is no one who would require from the individual a verification of what he/she is capable of).

Adhering to the named criterion of the "life meaning" in the existence of human individuals, we can use these positions to describe the selected forms of addressing difficult life situations:

- Self-destruction, a behavior that, in terms of common sense, has no real meaning. When viewed from the outside, self-destruction may seem to be a manifestation of a person's activity. This happens when a person is unable to cope with his/her reactions to a difficult life situation: they behave unrestrainedly, impulsively, putting themselves at undue risk. In fact, in transactional analysis such behavior is regarded as passive, representing a parallel to children's field behavior (the child's excessive responsiveness to environmental stimuli). In its extreme manifestations, it is a "strategy of dying" (for example, self-destruction under the pressure of difficulties through alcohol, drug and other types of addictions).

- Defense implies pseudo-awareness of actions in a DLS, a placebo of meaning. In this case the motives of underlying levels ("motives-incentives") rather than the primary motives (the highest position in the motivational hierarchy, "semantic motives") are realized. N. McWilliams distinguishes between primitive defenses and high-level defenses, wondering "what is wrong with" the former compared to the latter. Her answer is that our understanding of "defenses" as associated with pseudo-awareness is broader, and, as we can see, it covers the defenses of both levels.

- Coping is meaningful behavior, with the goal of solving a DLS. This interpretation seems quite obvious, since overcoming difficulties has a clear perspective in the form of an answer to the questions "Why?" and "What for?"; and they, in turn, are determined by motives that occupy high positions in the hierarchy of personal preferences.

- Mastering is the overcoming of difficulties of difficulties followed by learning a lesson/meaning (Petrovsky, 2013). In culture there are words that accurately express the semantic nuances of the phenomena of transcending difficulties and learning "lessons-meanings": self-possession, self-control, self-command, self-testing, self-identity of a person, etc. (more in Shmelev, 2017). Here meaning is revealed as a result of the personality trying its capabilities. One of the varieties of such a test is described as the phenomenon of passing an "emotional flutter", in which a person under no coercion resolves a situation of uncertainty and risk ("emotional flutter").

The "emotional flutter" means a state of heightened tension and instability associated with the uncertainty of a positive or negative outcome (Ibid., p. 72). The

\footnotetext{
${ }^{9}$ In all cases, it is necessary to keep in mind the distinction between the effects of completed acts of handling DLS and the initial aspiration of a person manifested in these acts. Any of the four selected forms of handling DLS can have positive or negative outcomes, but in mastering behavior the experienced unpredictability of outcomes is an inalienable "part" of the action itself.
} 
exact definition of the "flutter" (long before supersonic speeds appeared) was found in a context of gaining religious experience by the priest Fr. Pavel Florensky in the book "The Pillar and Ground of the Truth": "I give up the trembling fear of what will happen to me, and with a decisive gesture I am doing an operation for myself. I leave the edge of the abyss and with firm steps hasten onto the bridge, which, perhaps, will fail under me ... <..> ... This entry by an individual onto the existential "bridge" is a way to the unknown that opens up new horizons of faith for the person ..." (Florensky, 2003, pp. 67-68). At the same time, the person learns an important lesson, which gives meaning to a new test (Shmelev, 2017, p. 72).

It follows from the above that not all forms of handling difficult life situations are meaningful a priori. Here we fundamentally disagree with the position of $\mathrm{V}$. Frankl (see "Man's search for meaning ... Is the search always meaningful?" in Petrovsky, 2013). We should emphasize that in Frankl's philosophy the meaning is pre-existent to "the search for meaning," and at the same time "the meaning is always there, it only needs to be found." But we say: No, not always (about the illusion of the preexistence of meaning, see Petrovsky, 2013; Shmelev, 2017).

\section{The Culture of Individual Experience: the "Inversions" of Meaning}

Personal meaning is another matter. It always shows the person's attitude to what he/she is doing. As a rule, the person believes that everything he/she creates is meaningful (Petrovsky, 2013). Personal meaning always exists determined by the extent of the person entering into a relationship with themselves as an actor. As a rule, the person will insist on the meaningfulness of his/her own actions, even when, from the point of view of most people (from the point of view of common sense), his/her actions are estimated as ridiculous. Thus, a two-dimensional model of the methods of handling DLS is not enough to fully describe what is happening.

We offer a three-dimensional model, in which the third dimension consists of the person's attitude towards themselves as the subject that addresses a DLS, expressing themselves in the personal meanings of the acts undertaken. The third dimension is based on the construct of "attitude" that has a long history in the philosophy of culture (K. Marx, E. Cassirer, E. Husserl, E. Mounier, E. Gilson, J. P. Sartre, I. K. Mamardashvili, etc.) and psychology (D. Winnicott, J. Bowlby, M. Klein, O. Kernberg, H. Kohut; A. F. Lazursky, M. Ya. Basov, V. N. Myasishchev, F. Ye. Vasilyuk, S. L. Rubinstein, E. B. Starovoytenko and others).

The analysis of the "attitude" category is not part of the objective of this study. Here we shall confine ourselves to a working definition, according to which "attitude" is the distance experienced between the I and the Object that is dynamic in nature and resides between the "poles" of the "I $\equiv$ Object" merge and the opposing "I $\leftrightarrow$ Object". We believe that the "attitude" implies different degrees of the freedom of an individual as a subject of activity: the more tightly the I and the Object are "linked", the less free the person is in his/her manifestations; the greater the distance is, the more liberated the person is. This understanding seems to correspond to the views of S. L. Rubinstein in his book "Man and the World" 
(Rubinstein,); a multifaceted development of his ideas is found in the cycle of works by E. B. Starovoytenko (Starovoytenko, 2010; 2015).

We shall call the phenomenologically distinguished "point" of the I in the space of possible attitudes towards the Object a meta-position, and we shall hypothetically describe what meanings a person is able to endow the form of handling DLS. In doing so, we may be dealing with some unobvious results:

- Self-destruction can be justified (comprehended) in a variety of ways, including such as "paying for personal sins", "working off karma", "such is fate", etc. Such forms of rehabilitating self-destruction in everyday language may be called "excuses", but the person themselves may see them as full of meaning.

- Defense may be interpreted by a person as a necessary and natural coping strategy to address the situation (for example, a primitive protective mechanism of "isolation" in the form of spontaneous sleep can be recognized as a condition for "recharging" for future use, which means coping for the subject). On the other hand, the defense can become a pretext for self-accusation, for interpreting one's position as surrender in the face of difficulties, when a person suddenly feels that he/she is "burying his head in the sand" (while isolating), "looking for a lighter spot" (when repressing), "losing way in broad daylight" (during regression), "letting off steam" (when acting out), etc.

- Coping can be interpreted by a person as a manifestation of weakness (in the case of a search for support, "call a buddy"), as rationalizing (search for information, reflection), as a manifestation of one's own heartlessness (distancing as overcoming negative experiences by reducing the significance and the degree of emotional involvement), as the construction of "castles in the air" (planning for problem-solving). Without knowing the special terms, people easily find words that replace the names of defenses that exist in psychology and psychotherapy. It is also possible to "improve" the status of coping in the direction of mastering. It seems to a person that the efforts shown are a way of self-testing, proof of their abilities and courage, an experience of transcending difficulties through the testing of own capabilities. At the same time such a "transcendence" may be a super incentive to handle a DLS, which, as is known from the Yerkes-Dodson law, is not the optimal way to stimulate achievements.

- mastering behavior (from the point of view of life meaning) is a manifestation of active non-adaptability that originates in an excess of forces, one of the variants of "supra-situational activity". But at the same time the person may think that he/she uses the only chance to resolve the situation, that "there is no way back" (as it might have been when first overcoming a flutter), that "everybody would act like that in his/her place". In other words, mastering behavior is considered in the individual's consciousness as reduced to the rank of coping.

Sometimes giving in to the need to cope with own destructive impulses can be interpreted by a person as mastering, or transcending difficulties.

There are opposing "inversions" of meaning when mastering behavior is experienced by the person as self-destruction ("jumping in at the deep end"), although such actions (that seem to the person to be reckless) can be justified by the situation. And vice versa: a behavior in the face of difficulties that consists in the need 
to restrain one's impulses, not to be tempted, not to put oneself at risk, is characterized by lack of restraint, lack of control, passion of fearlessness, and spontaneity, which, of course, involves negative consequences (self-destruction under the guise of mastering behavior). "I know that this is ridiculous, but I will do it anyway!"; "I feel that I should keep silent, but I must say!”; “... I'm standing on thin air, // I drink the wind, I gulp the fog, // I experience terrible joy // that I am lost, I am lost ..." (but at the same time, "along the precipice, over the abyss, along the very edge // I flay my horses with a whip, I skin them ...) (V. Vysotsky).

Sometimes it is very difficult to distinguish between different forms of dealing with danger, even when we try to understand what is happening by taking the position of the subject of activity, that is, being guided by the personal meaning of what is happening. The phenomenon of Valery Chkalov could be an example of the ambiguous interpretation of "dealing with danger" (he was an "air hooligan", according to one version, and an outstanding pilot, according to another). The story of Chkalov, who for his love of risk, "flew a loop" under the Trinity Bridge in Leningrad, turned out to be a myth believed by millions of people after the release of M. Kalatozov's film "Valery Chkalov in 1941". The truth was that Chkalov had been in prison for his fantastically audacious aerial stunts, before Stalin lifted him to the rank of hero. But the reality was, according to the recollections of his elder sister, he did swim across the Volga at the age of eight and would dive under the rafts of the floating trees. What does all this mean: mastering behavior? Coping? Defense? Or, perhaps, self-destruction as the inability to resist the "irrational impulse" of the Thanatos (according to S. Freud)? To the latest version: "All, all that threatens to destroy, Holds for the mortal heart a joy Of inexplicable delight"10 (A. S. Pushkin).

As you can see, the presence of the "I" in a meta-position (that makes it possible to impart personal meaning to the four selected means of handling DLS) can lead to rearrangements in this "quartet" by way of replacing coping with defense, defense with self-destruction, self-mastering with mastering, mastering with copings, etc.

Acknowledging the possibility of such permutations, we shall raise the question of what caused the observed transformations.

It is easy to make certain that each of the methods of subjective "reading" of any four forms described contains cultural prototypes: culture here sets the patterns and anti-patterns of behavior that underlie a person's "self-understanding" in DLS (Figure 2).

\section{Dealing with Difficulties: the Ideofield of Culture}

Here, the "Great Ideofield of Culture" opens up in front of us (Mukhina, 2009 ${ }^{11}$ ). Religion, myths, parables, art, folklore, heroes of books and fairy tales, characters of jokes, film characters, etc., contain patterns and anti-patterns of how people behave in difficult life situations.

\footnotetext{
${ }^{10}$ Translated by Nancy K. Anderson

${ }^{11}$ See Petrovsky (2016) on the concept introduced by V. S. Mukhina.
} 


\section{Conflict of Interpretations: the Cultural Mediation}

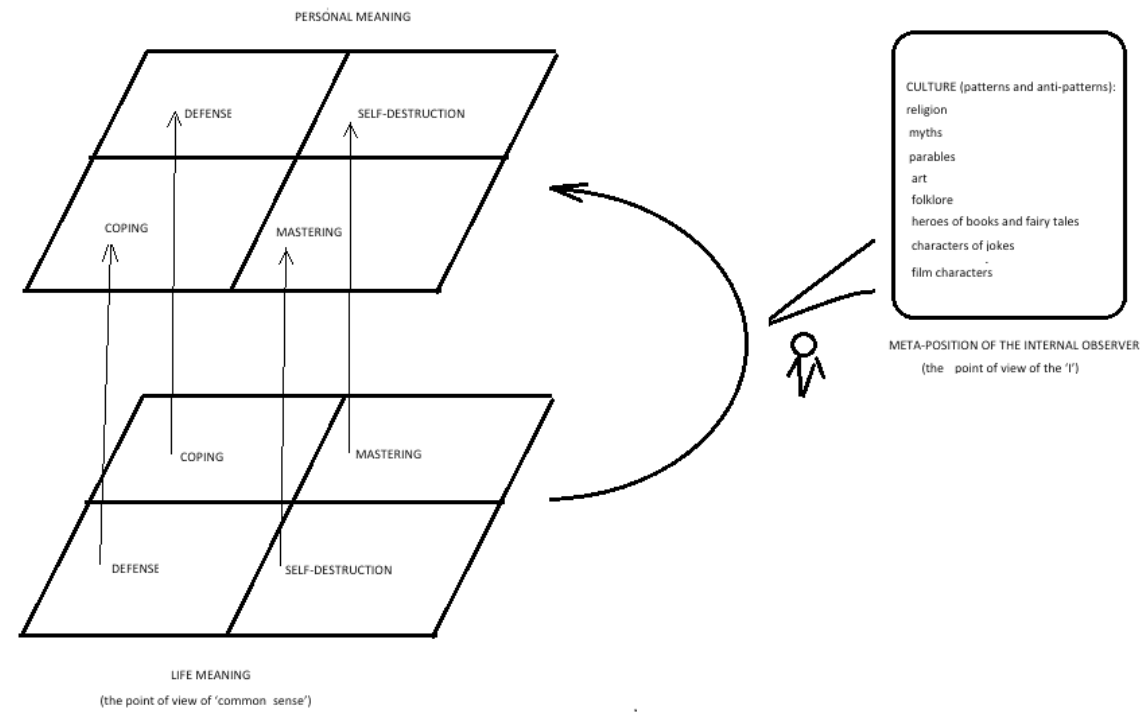

Artistic images in the works of F.M. Dostoevsky can make an example of cultural prototypes of self-destruction (in the form of anti-patterns) (Kirillov "freely" killing himself and, thereby, "liberating" humanity in his face from the fear of death), the non-commissioned officer's widow, who, according to the town governor, in "The Inspector-General" of N. Gogol, "flogged herself", the "Fatalist" of $\mathrm{M}$. Yu. Lermontov and many others.

Psychological defenses (as a negative phenomenon) are presented in many works of the classics (for example, repression, etc., explaining the behavior of Anna Karenina and Karenin himself'" ; "The Wise Gudgeon," "The Man Who Lives in a Shell" (A. Chekhov) are also negative patterns of protective behavior rooted in the public consciousness. It is important for us that the cultural image of defense mechanisms differs significantly from the interpretations presented in the special (psychoanalytic) literature, where "defenses" are considered as fundamental (core) constituents of character, and, therefore, they should not be "left out" as selfinflicted evil.

Coping is another thing. In this matter, culture is unanimous, starting with the image of the mouse that churns up the butter and thus gets out, and finishing with the cunning and heroic ways out of incredible situations in the works of writers, playwrights, journalists, narrators of various genres (the heroes of coping live on

${ }^{12}$ In the Soviet Union, where Freudian psychoanalysis was not in much favour, the first attempt to legalize the idea of defense mechanisms in a psychology textbook for universities (we emphasize, a textbook!) was made in the 60 s by A. V. Petrovsky using the example of the analysis of Karenin's personality, a character of the novel "Anna Karenina" by L. N. Tolstoy. 
pages of millions of books, stories, and essays, inspiring readers to overcome adversity and difficulties, and fight for life). In these written (and oral) stories copings possess the ultimate value and are the standard of effort in difficult life situations.

Mastering behavior is also part of works of art and art. All that is covered by the category of "feat", including mastering behavior, is presented in many forms in literature, theater, and cinema. The feat always means going beyond the limits of something given, required, rationed, or due. The original act that exceeds the dictate of society. But mastering behavior is not obvious ("not rationalized") according to its origins: "Madness of the brave we sing a song” (M. Gorky).

Folklore is another part of the Ideofield of Culture. Among the numerous examples of patterns and anti-patterns that induce or repulse certain behaviors in a DLS, we shall choose only one example from the "Proverbs of the Russian people" by Vladimir Dahl, expressing more precisely the peculiarities of the national mentality: "Yes ... This is not a good thing ... But let us try! ..." (mastering ${ }^{13}$ ). The peculiarities of the ethno-cultural determination of the forms of addressing DLS and the ways of understanding these forms can be the subject of a special study. In Russian culture, in contrast to Japanese culture, it seems unlikely that such proverbs inspiring coping could have taken root: "if you see a big wave, duck your head under", "tot up your losses before you declare a profit”, "before boxing someone's ears look at whose head it is". However, it cannot be emphatically said that such proverbs are specific to Japanese culture: a large-scale comparative analysis of a large array of Russian and Japanese proverbs is necessary (not only philological, but also psychological, from the point of view of perception and evaluation of existential significance).

Due to the fact that the Ideofield of Culture is significantly expanding through the "Internet folklore" (it sounds paradoxical, but the people doesn't not remain silent!), there have been new witty examples of cultural prescriptions relevant to different faiths; they "teach" how a person should behave if a "misfortune" suddenly came (another word is used in the original texts).

- Buddhism: If "misfortune" happened, then in reality it is not "misfortune".

- Hinduism: This "misfortune" happened before too.

- Catholicism: The "misfortune" happened because you were bad.

- Orthodox, Has "misfortune” happened? Well, wear it.

- Judaism: And why is this "misfortune" happening only to us?

In the Internet folklore we also find the parodically expressed principles of reacting to difficult life situations in various psychotherapeutic systems:

- Gestalt approach: If "misfortune" happened, experience it.

- Freudism: "Misfortune" happened in early childhood.

- Jung: The fact that the "misfortune" happened is a manifestation of the Great Mother's archetype.

- Hellinger: This "misfortune" happened yet to my great-grandmother.

- Berne: This "misfortune” happened because I have got a loser's script.

(The use of the decent replacement word "misfortune" unfortunately reduces the instructive and psychotherapeutic effect of the proposed insights and teachings).

\footnotetext{
${ }^{13}$ The readers should judge themselves whether this is a pattern or an anti-pattern of behavior.
} 
Of course, these humorous "generalizations" do not in any way express the deep essence of the ideas presented by world religions and psychotherapeutic systems. But we are primarily interested in how these complex ideas "live" in the everyday consciousness of people that is contradictory and inconsistent, including in the perception of representatives of psychotherapeutic "confessions" who always ridicule each other.

Earlier we noted that the "I", occupying a meta-position at different distances from the plane of the four forms of addressing DLS, has the freedom to choose ways of understanding what is happening.

But this means that when entering into a dialogue with the "I", the psychologist-practitioner (consultant, psychotherapist, coach) can influence the person as a subject of self-understanding and, accordingly, the behavior in a DLS.

\section{Practice. Synthesis of the "Three Cultures" as a Guide for Handling Difficulties}

In this case, there is a union (synthesis) of the three cultures for mediating human activity in difficult life situations: the culture of psychological knowledge, the Ideofield of Culture and the culture of individual experience. As a result, a state of consciously and rationally addressing difficult life situations can be achieved in a person to overcome illusions and prejudices overshadowing the reality of actions taken and attitudes towards them.

As an illustration, we shall give two ways of rebuilding a person's attitude to difficult life situations.

- A technique for working with metaphoric cards

Metaphoric Associative Cards (MAC) and Coaching Associative Cards $\left(\mathrm{CAC}^{14}\right)$, unlike some other options.

The client is offered to draw on an A4 sheet the "line of his/her life" and note the periods when he/she had little experience, as well as periods of gaining experience. It is important to remember the key decisions, as well as "what made you who you are now". It is necessary to draw the line from left to right, mark on it the points of the main events, and comment on them using one or two words. The year of birth and the date of the session are also indicated.

The coach says: "Choose a card, a word, and a picture card that symbolize your experience until today. What is shown on the map? What is the metaphor image?

${ }^{14}$ The "CAC" cards are an opportunity to use an additional tool in the work of a professional coach, both a life-coach and a specialist in business and executive coaching. The "CAC" cards consist of two decks, the first deck has cards containing different coaching models, the second one has cards with images revealing possible contents of the models used. There are a large number of different card combinations when two decks are used together. The main feature of this deck is its wide applicability in coaching practice that enables applying both to one's own personal potential indicated as the second I (DAVID, couldn't find anything like that in references) by one of the co-founders and developers of coaching Timothy Gallwey, and to the resources of human consciousness and intellectual experience (Shmelev \& Gracheva, 2017). 
How does this relate to your experience? What is the value of your experience? How has it influenced your life? What are you grateful to your experience for? What decisions did you make that allowed you to travel the path and appear where you are? What is the meaning of this experience for you?"

Next: "Take a look at your entire life. Specify what you would like to achieve, and what qualities you would like to acquire in the next few decades (to build a relationship, to get a promotion, etc.). So, imagine that 10 years have passed. Choose a word map card and a picture card symbolizing your achievements after 10 years. What is shown in the picture? What is the metaphor image? How does this metaphor image relate to what you have achieved in 10 years? What is the value of your experience in this decade? How has it influenced your life? What are you grateful to your experience for? What decisions did you make that allowed you to travel the path and attain what you have attain over the ten years? What is the meaning of this experience for you?"

Then the next 10 years (and so on ascending 4 to 5 times).

"... So, you are at the edge of your life and you look back. Choose a card, a word card and a picture card symbolizing your achievements by this time... What was your main life purpose or a leitmotif of your life in the light of the previous answers? For what are you grateful to yourself? What are you grateful to your experience for? What is the value of your life experience? How has it influenced your life? What could you wish to yourself in the "past" from yourself "on the edge of a life lived"?

Take a look at yourself ("as if" you were an outsider) and examine the line of your life. What decisions were the most important in your life? What was the meaning of your life for you?

Now enter the "point" of the present and make new decisions regarding your future.

Thank yourself for the work."

- A technique of working with TAT modification

Working with a client is different than it is in working with projective techniques.

Consultant: "Make as accurate as possible a psychological picture of the character in the picture. Look at the image. What will your intuition tell you? This situation may in some ways resemble incidents from your own life; but try to speak only about what you see in front of you. Assume the role of a psychologist who is constructing a psychological portrait of this character.

Consider that you know something about this situation. For example, you know that all this has happened many times in the life of this character... The woman cried, avoided people, and felt hopeless... What does she think or feel, what will she do? How will this situation end? What thoughts will visit the character in the picture? What conclusions will be made? What will be the character's thoughts about themselves in the end? How reasonable is the behavior, are the thoughts justified, are the estimates adequate? What alternatives are there?"

The last questions in the series give rise to a "session" shared with the client of counseling, therapy, and coaching for the virtual character. Near the end of the 
"session" the psychologist asks the client about the difference between the response of the virtual character to a difficult life situation depicted in the picture, and how the client would see themselves in such a situation. Thereby there is a distinction partly made between the perceived ("I feel, think and behave differently than the character") and unconscious ("what happens not with me, but with the virtual character") patterns.

The inversion of roles of the real client and the virtual client creates a wonderful opportunity to work with the client ("what would the character in the picture say about you as a person in this difficult life situation?”). This technique, in particular, allows the client (in the course of further work) sometimes "on the chairs", to rethink, or, in transactional and analytical terms, "redefine" the existing forms of dealing with the situation (Petrovsky, 2001).

Upon completion of the work, the consultant may ask what the client has discovered during the shared activity.

The conditional situations offered by the consultant in one case (metaphorical cards) are symbols of what is happening (indefinite and multivalued, like any symbol); in the other case, these are signs of reality, illustrations of life situations in which the client resides. With all the differences in the cultural symbols and signs involved, they acquire a unique meaning in contact with the client's individual experience, an "emergent" property ${ }^{15}$, not directly recorded in them. According to one of the founders of semiotics, C. Morris, this is a predisposition to action (it is between the sign and the action). We consider it important to note that a certain "increment" to the understanding of a situation takes place that initially turned it into a "difficult" one. In other words, between the sign and the action, in the very predisposition to the action, it is planned to go beyond the limits of the image of a situation prevailing in the individual's mind, and, thus, its rethinking. Now, the forms of dealing with difficult life situations previously undertaken or planned by the client are analyzed or evaluated in terms of their possible life meaning: is it coping? Defense? Mastering? Self-destruction? What are the results? What "parts" of the personality are involved in it? And so on. As a result of teamwork with the client, the client's personal meanings correlate in his/her mind with the "life meaning" of this action as understood by the consultant. At the same time, the consultant proceeds from his/her own professional competences (psychological knowledge, clinical experience), but the client has the right to choose how to understand the situation and what to do next.

Thus, the culture of individual experience, the ideofield of culture and the culture of scientific knowledge come together in the work with metaphorical cards and projective pictures. "If a person goes from a point where knowledge does not help, he/she goes in the direction of meaning" (M. K. Mamardashvili).

The client walks along this path together with the consultant.

${ }^{15}$ The "emergent" (generated) property in this case is like a spark running between a person and a symbol (sign), giving rise to a unique semantic meaning, the "reading" of the symbol/sign. In this way, the personal meaning of the individual's acts of dealing with difficult life situations is revealed. 


\section{Conclusions}

1. Psychology of difficult life situations (DLS) has an inherent "equilibrium of deficits": psychotherapists and consultants lack the accuracy of individual test diagnostics in the case of a DLS, while "academic psychologists" lack the subtleties of phenomenological analysis. Cultural psychology of the individual is the condition for the synthesis of theoretical-empirical and practice-oriented approaches to the understanding of the personal manifestations of an individual in DLS.

2. In the general landscape of culture, the interpretation of DLS and the attitude to difficulties there are the paradigms of scientific knowledge, the ideofield of culture, and the culture of individual experience.

3. The "conformity (in the broad sense, adaptability) postulate" is the dominant form of understanding personal manifestations in DLS in the interpretation of human behavior and consciousness, which limits the range of categories of typology for the individual forms of addressing difficulties.

4. There are four forms of personal handling DLS: self-destruction, defense, coping and mastering.

5. A two-dimensional typology of the forms of handling DLS is proposed based on the distinction between "activity/passivity" and "adaptability/non-adaptability": self-destruction is characterized as passive non-adaptive behavior; defense as passive adaptive behavior (adaptation to the situation); coping as active adaptive behavior (overcoming the situation); mastering as active non-adaptive behavior (overcoming difficulties).

6. Three ways of mastering are described: post-factum simulation of situations; a testing of the individual's capabilities in a previously unknown situation ("emotional flutter"); and "emergency simulation for future use".

7. Unique ways of understanding by the individual their own behavior in a DLS generate a picture of the discrepancy between the forms of the person's addressing DLS and their interpretation from the "I" position.

8. A model of the personological synthesis of the three cultures of interpreting human activity in difficult life situations is presented, including the techniques of coorganizing individual experience, the Ideofield of Culture and scientific knowledge.

\section{References}

Allport, G. (2002). Stanovlenie lichnosti. Izbrannye trudy [Formation of personality: Selected works]. Moscow: Smysl. (in Russian)

Asmolov, A. G., Chernorizov, A. M., \& Shekhter, E. D. (2017). Preadaptatsiya k neopredelennosti kak strategiya navigatsii razvivayushchikhsya sistem: marshruty evolyutsii [Preadaptation to uncertainty as a strategy to naviagate developing systems: evolutionary paths]. Voprosy Psikhologii, 4, 3-26. (in Russian)

Berne, E. (2017). Seks v chelovecheskoi lyubvi [Sex in human love]. Moscow: Eksmo. (in Russian) 
Bityutskaya, E. V. (2018). Tipy orientatsii v trudnykh situatsiyakh [Types of orientations in difficult situations]. Voprosy Psikhologii, 5, 41-53. (in Russian)

Bityutskaya, E. V., \& Petrovsky, V. A. (2016, September). K voprosu o sub"ektivnoi i ob"ektivnoi trudnosti zhiznennoi situatsii [On the issue of the subjective and objective difficulties in a life situation]. In T. L. Kryukova, M. V. Saporovskaya, \& S. A. Khazova (Eds.), Psikhologiya stressa i sovladayushchego povedeniya: resursy, zdorov'e, razvitie: Materialy IV Mezhdunarodnoi Nauchno-prakticheskoi Konferentsii [Psychology of stress and coping behavior: resources, health, and development: materials of the IV International scientific conference] (Vol. 2, pp. 17-19). Kostroma: KGU im. N. A. Nekrasova. (in Russian)

Durkheim, E. (1995). Sotsiologiya: Eyo predmet, metod, prednaznachenie [Sociology: its subject, method, and purpose]. Moscow: Kanon. (in Russian)

Erikson, E. (2002). Detstvo i obshchestvo [Childhood and society]. Saint Petersburg: Rech'. (in Russian)

Filippov, A. V., \& Kovalev, S. V. (1986). Situatsiya kak element psikhologicheskogo tezaurusa [The situation as an element of the psychological thesaurus]. Psikhologicheskii Zhurnal, 7(1), 14-21. (in Russian)

Florensky, P. A. (2003). Stolp i utverzhdenie istiny. Opyt Pravoslavnoi Teoditsy [The pillar and ground of the truth. An experience of Orthodox theodicy]. Moscow: AST Publishing house. (in Russian)

Folkman, S., \& Lazarus, R. S. (1998). Coping as a mediator of emotion. Journal of Personal and Social Psychology, 54, 466-475.

Frydenberg, E., \& Lewis, R. (2000). Teaching coping to adolescents: when and to whom? American Educational Research Journal, 37(3), 727-745.

Haan, N. (1965). Coping and defense mechanisms related to personality inventories. Journal of Consulting Psychology, 29, 373-378.

Haan, N. A. (1969). A tripartite model of ego functioning, values and clinical and research applications. Journal of Nervous and Mental Disease, 148(1), 14-30.

Haan, N. (1977). Coping and defending: Processes of self-environment organization. New York: Academic Press.

Koplik, E. K., Lamping, D. L., \& Reznikoff, M. (1992). The relationship of mother-child coping styles and mother's presence of children's response to dental stress. Journal of Psychology, 126(1), 79-92.

Kroeber, T. C. (1963). The coping functions of the ego mechanisms. In R. Write (Ed.), The study of lives (pp. 178-198). New York: Atherton Press.

L'vova, E. N., \& Shlyagina, E. I. (2016, September). Sovladayushchee povedenie: o sootnoshenii osoznavaemogo i neosoznavaemogo [Coping behavior: on the ratio of the conscious and the unconscious]. In T. L. Kryukova, M. V. Saporovskaya \& S. A. Khazova (Eds.), Psikhologiya stressa i sovladayushchego povedeniya: resursy, zdorov'e, razvitie: Materialy III Mezhdunarodnoi nauchnoi konferentsii [Psychology of stress and coping behavior: resources, health, and development: materials of the IV International scientific conference] (Vol. 1, pp. 48-49). Kostroma: KGU im. N. A. Nekrasova. (in Russian)

Lasarus, R. (2006). Emotions and interpersonal relationships: toward a person-centered conceptualization of emotions and coping. Journal of Personality, 74(1), 9-43.

Lazarus, R. S., \& Folkman, S. (1984). Stress, appraisal and coping. New York: Springer Publ. Company. 
Libina, A. V. (2008). Sovpadayushchii intellekt: chelovek v slozhnoi zhiznennoi situatsii [The coping intelligence: a person in a difficult life situation]. Moscow: Eksmo. (in Russian)

Lisetsky, K. S., \& Lityagina, E. V. (2014). Addiction: pecularities and interrelation of attitude to the disease of drug addicted and co-dependents]. Vestnik of Samara University, 9(120), 251-256. (in Russian)

Litinskaya, D. G. (2012). Ekzistentsial'nyi eskapizm kak sotsiokul'turnyi fenomen sovremennogo obshchestva [Existential escapism as a sociocultural phenomenon of modern society] (Ph.D. thesis). Moscow University for Humanities, Russian Federation. (in Russian)

Maslow, A. (1981). Teoriya Z. In A. Maslow. Motivatsiya i lichnost' [Motivation and personality] (3rd ed.). Saint Petersburg: Piter. (in Russian)

McWilliams, N. (2016). Psikhoanaliticheskaya diagnostika. Ponimanie struktury lichnosti v klinicheskom protsesse [Psychoanalytic diagnostics: Understanding the personality structure in the clinical process]. Moscow: Klass. (in Rusian)

Moscovici, S. (1995). Sotsial'nye predstavleniya: istoricheskii vzglyad [Social views: a historical view]. Psikhologicheskii Zhurnal, 1, 3-19. (in Russian)

Mukhina, V. S. (2009). Velikoe ideopole obshchestvennogo samosoznaniya - fenomen global'noi kul'tury [The great ideofield of social self-consciousness: a phenomenon of global culture]. Razvitie Lichnosti, 4, 29-39. (in Russian)

Nartova-Bochaver, S. K. (1997). "Coping behavior" v sisteme ponyatiya psikhologii lichnosti ["Coping behavior” in the system of concepts of personality psychology]. Psikhologicheskii Zhurnal, 5, 25-30. (in Russian)

Petrovsky, V. A. (1975). K psikhologii aktivnosti lichnosti [To the psychology of personality activity]. Voprosy Psikhologii, 3, 26-38. (in Russian)

Petrovsky, V. A. (1993). Fenomen sub"ektnosti v psikhologii lichnosti [The phenomenon of subjectness in the psychology of personality] (Doctoral dissertation). Institut pedagogicheskikh innovatsii RAO, Moscow, Russian Federation. (in Russian)

Petrovsky, V. A. (1995). Ideya "Ya=Mir" v razvitii lichnosti [The idea of the "I = World" in the development of personality]. Novye Tsennosti Obrazovaniya, 3, 27-37. (in Russian)

Petrovsky, V. A. (2003). Obshchaya personologiya: nauka lichnosti [General personology: The personality science]. Izvestiya Samarskogo Nauchnogo Tsentra Rossiiskoi Akademii Nauk. Special issue "Aktual'nye problemy psikhologii”, 20-30. (in Russian)

Petrovsky, V. A. (2008). Opulence and reflection: four resources model]. Psychology. Journal of the Higher School of Economics, 5(1), 77-100. (in Russian)

Petrovsky, V. A. (2009). Logika "Ya": personologicheskaya perspektiva [The logic of the "I": A personal perspective]. Samara: SAMGU Publishing House. (in Russian)

Petrovsky, V. A. (2010). Chelovek nad situatsiei [The person over the situation]. Moscow: Smysl. (in Russian)

Petrovsky, V. A. (2013). "Ya" v personologicheskoi perspective [The "I" in a personological perspective]. Moscow: HSE Publishing House. (in Russian)

Petrovsky, V. A. (2015). "Ideopole": opyt personologicheskogo prochteniya (k 80-letiyu V. S. Mukhinoi) [The "ideofield": the experience of a personological interpretation (to the 80th anniversary of V. S. Mukhina)]. Razvivayushchie Lichnosti, 1, 21-29. (in Russian) 
Petrovsky, V. A., \& Ognev, A. S. (1996). Osnovnye polozheniya psikhologii sub"ektogeneza [The main provisions of psychology of subject-genesis]. Ezhegodnik Rossiiskogo Psikhologicheskogo Obshchestva, 2(1), 11-12. (in Russian)

Petrovsky, V. A., \& Starovoytenko, E. B. (2012). The Science of personality: Four projects in general personology. Psychology. Journal of the Higher School of Economics, 9(1), 21-39. (in Russian)

Petrovsky, V. A., \& Yaroshevsky, M. G. (1998). Osnovy teoreticheskoi psikhologii [Fundamentals of theoretical psychology]. Moscow: INFRA-M. (in Russian)

Rogers, C. (1951). Client-centered therapy. Boston, MA: Houghton Mifflin.

Shmelev, I. M. (2015). Emotsional'nyi "l'stets" i ovladevayushchee povedenie: "mezhprostranstvennyi" perekhod [The emotional "flutter" and mastering behavior: an "interdimensional" transition]. Mir Psikhologii, 84(4), 111-123. (in Russian)

Shmelev, I. M. (2017). Sootnoshenie tipov religioznosti i sposobov razresheniya trudnykh zhiznennykh situatsii [Correlation of types of religiosity and ways of resolving difficult life situations] (Ph.D. thesis). National Research University Higher School of Economics: Moscow, Russian Federation. (in Russian)

Simonov P. V. (1975). Vysshaya nervnaya deyatel'nost' cheloveka. Motivatsionno-emotsional'nye aspekty cheloveka. Motivatsionnye i emotsional'nye aspekty [Higher nervous activity of a person. Motivational and emotional aspects]. Moscow: Nauka. (in Russian)

Starovoytenko, E. B., \& Isaeva, A. N. (2016). The model of analysis of personal relationships on the basis of "oppositional principle". Psychology. Journal of the Higher School of Economics, 13(4), 741-762. (in Russian)

Starovoytenko, E. B. (2004). Psikhologiya lichnosti v paradigme zhiznennykh otnoshenii: uchebnoe posobie dlya studentov i aspirantov vuzov, obuchayushchikhsya po spetsial'nostyam "Psikhologiya" [Personality psychology in the paradigm of life relations: a textbook for undergraduate and postgraduate students of higher educational institutions studying the Psychology specialty]. Moscow: Triksta. (in Russian)

Starovoytenko, E. B. (2010). Modeli zhiznennykh otnoshenii lichnosti v kontekste ontopsikhologii S. L. Rubinshteina [Models of life relations of a personality in the context of ontopsychology of S. L. Rubinstein] (pp. 349-379). In K. A. Abulkhanova (Ed.) Sergrei Leonidovich Rubinshtein. Moscow: ROSSPEN. (in Russian)

Starovoytenko, E. B. (2015). Personologiya: zhizn' lichnosti v kul'ture [Personology: the life of the individual in culture]. Moscow: Akademicheskii proekt. (in Russian)

Starovoytenko, E. B. (2016). Genez Ya v otnosheniyakh k Drugomu [The genesis of the I in relation to the Other]. In Psikhologicheskie issledovaniya lichnosti: istoriya, sovremennost', perspektivy [Psychological studies of personality: history, current state, and prospects] (pp. 117-135). Moscow: Kogito-Tsentr. (in Russian)

Tobalov, Yu. P. (2004). Sovladanie s trudnymi zhiznennymi situatsiyami u veruyushchikh: na materiale pravoslavnykh khristian i musul'man [Coping with difficult life situations of believers: based on the material of Orthodox Christians and Muslims] (Ph.D. thesis). Russian State Social University, Moscow, Russian Federation. (in Russian)

Vaillant, G. E. (1977). Adaptation to life. Boston, MA: Little, Brown. 
Vadim A. Petrovsky - professor, Department of Psychology, Faculty of Social Sciences, National Research University Higher School of Economics, Member of the RAE, D.Sc., professor.

Research area: personality psychology, consultative psychology, mathematical modeling of behavior and consciousness.

E-mail: petrowskiy@mail.ru

Ilya M. Shmelev - senior lecturer, Department of Psychology, Faculty of Social Sciences, National Research University Higher School of Economics.

Research interests: psychology of personality, personology, psychotherapy, psychology of religion, coaching, social and psychological training.

E-mail: shmelevilya@gmail.com 


\title{
Персонология трудных жизненных ситуаций: на перекресте трех культур
}

\author{
В.А. Петровскийа
}

${ }^{a}$ Национальньй исследовательский университет «Высшая школа экономики», 101000, Россия, Москва, ул. Мясницкая, д. 20

\section{Резюме}

Статья посвящена анализу феноменов обращения личности с трудными жизненными ситуациями (ТЖС). Обращение с ТЖС трактуется в контексте «трех культур» - во взаимосвязи культуры научного знания, «идеополя культуры» и культуры индивидуального опыта. Анализируются существующие теории реагирования индивида на трудные ситуации; показано, что методологическим ядром большинства концепций является «постулат сообразности» («адаптивности») в трактовке поведения человека. Наряду с общеизвестными «защитным» и «копинговым» поведениями, имеющими адаптивный характер, выделяются неадаптивные формы - «самодеструкция» и «овладевание» и предлагается двумерная типология форм обращения с ТЖС, основанная на различении «активности - пассивности» и «адаптивности - неадаптивности». Самодеструкция характеризуется как пассивно-неадаптивное поведение (дезадаптация); защита - пассивно-адаптивное поведение (собственно, приспособление к ситуации); копинг - активно-адаптивное поведение (преодоление ситуации); овладевание - активно-неадаптивное поведение (превосхождение трудностей). Выделяются три способа овладевания: моделирование ситуаций постфактум; испытание своих возможностей в ранее неизвестной ситуации - «эмоциональный флаттер»; «аварийное моделирование впрок». Рассматриваются также способы осмысления личностью собственного поведения в ТЖС, что трансформирует двухмерную модель в трехмерную, характеризующую отношение личности к трудным жизненным ситуациям. Показано, что в субъективном плане (смысловой аспект саморефлексии) «рисуемая» индивидом картина используемых способов обращения с ТЖС может существенно не совпадать с объективной картиной происходящего (устанавливаемой согласно критериям научного знания). Представлена модель персонологического синтеза трех культур интерпретации и соотнесения форм обращения личности с ТЖС. В этом контексте рассматриваются некоторые техники соорганизции индивидуального опыта, элементов «идеополя культуры» и научного знания, что способствует изменению отношения личности к трудным жизненным ситуациям и повышению осмысленности собственного поведения.

Ключевые слова: персонология, культура, трудная жизненная ситуация, обращение с трудностями, самодеструкция, защита, копинг, овладевание, смысл, отношение, метапозиция.

Петровский Вадим Артурович - профессор, департамент психологии, факультет социальных наук, Национальный исследовательский университет «Высшая школа экономики», доктор психологических наук, профессор, ординарный профессор НИУ ВШЭ, член-корреспондент РАО.

Сфера научных интересов: психология личности, консультативная психология, математическое моделирование поведения и сознания.

Контакты: petrowskiy@mail.ru 
Шмелев Илья Михайлович - старший преподаватель, департамент психологии, факультет социальных наук, Национальный исследовательский университет «Высшая школа экономики».

Сфера научных интересов: психология личности, персонология, психотерапия, психология религии, коучинг, социально-психологические тренинги.

Контакты: shmelevilya@gmail.com 